\title{
PENGEMBANGAN COMMUNITY BASED TOURISM SEBAGAI STRATEGI PEMBERDAYAAN EKONOMI MASYARAKAT DI KABUPATEN KULON PROGO, DAERAH ISTIMEWA YOGYAKARTA
}

\author{
Sugi Rahayu, Utami Dewi, dan Kurnia Nur Fitriana \\ Fakultas Ilmu Sosial Universitas Negeri Yogyakarta \\ email: sugirahayu@uny.ac.id
}

\begin{abstract}
Abstrak: Pengembangan Community Based Tourism sebagai Strategi Pemberdayaan Ekonomi Masyarakat di Kabupaten Kulon Progo, Daerah Istimewa Yogyakarta. Penelitian ini bertujuan untuk: (1) mengetahui upaya yang dilakukan oleh pemerintah Kabupaten Kulon Progo dalam mengembangkan Community Based Tourism (CBT), (2) mengidentifikasi potensi wisata yang dapat dikembangkan menjadi CBT, (3) mendapatkan informasi faktor-faktor penghambat CBT di Kabupaten Kulon Progo, dan (4) merumuskan model pengembangan CBT sebagai strategi pemberdayaan ekonomi masyarakat di Kabupaten Kulon Progo. Upaya Pemerintah Kabupaten Kulon Progo dalam mengembangkan CBT sebagai strategi pemberdayaan ekonomi masyarakat dilakukan melalui: (a) Program pengembangan destinasi wisata, (b) Program pengembangan pemasaran pariwisata, dan (c) Program pengembangan kemitraan. Sementara itu, jenis pariwisata yang potensial untuk dikembangkan menjadi pariwisata berbasis masyarakat di Kulon Progo meliputi wisata alam, wisata agro, wisata religi, wisata pendidikan, budaya, kerajinan, dan kuliner. Terdapat beberapa faktor penghambat pengembangan CBT di Kabupaten Kulon Progo yaitu: (a) infrastruktur yang belum mendukung, (b) partisipasi masyarakat dalam mengembangkan pariwisata masih rendah, dan (c) kemitraan belum terjalin maksimal.
\end{abstract}

Kata kunci: pengembangan pariwisata berbasis masyarakat, Kulon Progo

\begin{abstract}
Developing Community Based Tourism Strategy for Empowering Local Economy. This study was aimed at: (1) examining the efforts made by the government of Kulon Progo in developing Community based Tourism (CBT), (2) identifying the tourism potentials that can be developed into CBT, (3) obtaining information about the factors inhibiting CBT in Kulon Progo, and (4) formulating a model of the development of CBT as an economic empowerment strategy in Kulon Progo. The result shows the Government's efforts in developing CBT in Kulon Progo Regency as a strategy for economic empowerment namely: (a) the development of tourist destinations program, (b) the development of tourism marketing program, and (c) the partnership development program. (2) The type of tourism potential to be developed into community-based tourism in Kulon Progo include eco-tourism, agro tourism, religious tourism, educational tourism, culture, crafts, and culinary (3) factors inhibiting the development of CBT in Kulon Progo are: (a) infrastructure does notyet support, (b) community participation in developing tourism is still low, and (c) the partnership has not established a maximum.
\end{abstract}

Keywords: community based tourism, Kulon Progo 


\section{PENDAHULUAN}

Dikeluarkannya UU Nomor 32 Tahun 2004 tentang Pemerintah Daerah dan UU Nomor 33 Tahun 2004 tentang Perimbangan Keuangan Pusat dan Daerah, memberi kesempatan yang besar bagi daerah untuk mengelola sumber daya alam yang dimiliki agar dapat memberikan hasil yang optimal. Akibatnya setiap pemerintah daerah berusaha semaksimal mungkin untuk meningkatkan perekonomian daerahnya.

Pelaksanaan pembangunan daerah diarahkan untuk memacu pemerataan pembangunan dalam rangka meningkatkan pendayagunaan potensipotensi yang dimiliki secara optimal. Dalam melaksanakan berbagai kegiatan yang berkaitan dengan pelaksanaan daerah tentu memerlukan biaya yang cukup besar. Agar pemerintah daerah dapat mengurus rumah tangganya sendiri dengan sebaik-baiknya, maka perlu diberikan sumber-sumber pembiayaan yang cukup. Mengingat tidak semua sumber-sumber pembiayaan dapat diberikan kepada daerah, maka pemerintah daerah diwajibkan untuk menggali segala sumber sumber keuangannya sendiri berdasarkan peraturan perundangundangan yang berlaku. Salah satu upaya untuk meningkatkan penerimaan daerah yaitu dengan mengoptimalkan potensi dalam sektor pariwisata. Keterkaitan industri pariwisata dengan penerimaan daerah berjalan melalui jalur PAD dan bagi hasil pajak/bukan pajak.

Sektor pariwisata di Indonesia saat ini dinilai efektif peranannya dalam menambah devisa negara. Hal tersebut tidak terlepas dari perkembangan kebutuhan pariwisata, tidak hanya di Indonesia, namun di seluruh dunia. Pertumbuhan kebutuhan manusia akan pariwisata menyebabkan sektor ini dinilai mempunyai prospek yang besar di masa yang akan datang. Sektor pariwisata mampu menghidupkan ekonomi masyarakat di sekitarnya, pariwisata juga diposisikan sebagai sarana penting dalam rangka memperkenalkan budaya dan keindahan alam daerah terkait. Menurut Norval dalam Spillane (1987), seorang ahli ekonomi berkebangsaan Inggris memaparkan bahwa pariwisata selain bermanfaat bagi pendidikan kebudayaan dan sosial juga mempunyai arti yang lebih penting dari segi ekonomi. Banyak negara di dunia menganggap pariwisata sebagai invisible export atas barang dan jasa pelayanan kepariwisataan yang dapat memperkuat neraca pemasukan.

Pariwisata merupakan sumber pendapatan yang dapat terus diperbaharui dan diremajakan, bentuk peremajaan daerah wisata ini dapat berupa renovasi, dan perawatan secara teratur, oleh sebab itu maka pariwisata merupakan investasi yang penting pada sektor non migas bagi Indonesia. Pariwisata yang merupakan investasi ekonomi masa depan akan secara otomatis mempermudah perputaran barang dan jasa pelayanan di tempat wisata. Lebih jauh lagi pariwisata akan meningkatkan stabilitas ekonomi nasional, namun tentu saja keberhasilan dalam pengembangan pariwisata seperti di atas akan mampu dirasakan apabila faktorfaktor pendukungnya telah dipersiapkan dengan baik.

Kulon Progo merupakan salah satu kabupaten di Daerah Istimewa Yogyakarta (DIY). Mengacu kepada UU Nomor 32 Tahun 2004 dan UU Nomor 33 Tahun 2004 tersebut, Kulon Progo sebagai sebuah kabupaten memiliki wewenang sendiri untuk mengelola sumberdaya yang terdapat di wilayahnya, termasuk di dalamnya adalah potensi sumberdaya sektor pariwisatanya. Kabupaten Kulon Progo memiliki sektor pariwisata yang 
potensial untuk di kembangkan serta dipasarkan yaitu mulai dari pantai, seni, budaya, waduk wisata, goa dan dataran tinggi. Beberapa tujuan wisata di Kabupaten Kulon Progo adalah sebagai berikut.

a. Pantai Glagah di Kecamatan Temon

b. Pantai Trisik di Kecamatan Galur

c. Pantai Congot di Kecamatan Temon

d. Pantai Bugel di Kecamatan Panjatan

e. Puncak Suroloyo di Kecamatan Samigaluh

f. Goa Kiskenda di Kecamatan Girimulyo

g. Gunung Kuncir di Kecamatan Samigaluh

h. Gunung Kelir di Kecamatan Girimulyo

i. Goa Sumitro di Kecamatan Girimulyo

j. Goa Lanang Wedok di Kecamatan Pengasih

k. Goa Kebon di Kecamatan Panjatan

I. Goa Lanang di Kecamatan Temon

m. Goa Banyu Sumurup di Kecamatan Samigaluh

n. Arung Jeram di Sungai Progo

(Sumber: Perda Kabupaten Kulon Progo No. 1 Tahun 2012 )

Seluruh objek wisata di atas berada dalam kendali pemerintah Kabupaten melalui Dinas Kebudayaan Pariwisata Pemuda dan Olahraga Kabupaten Kulon Progo. Artinya, pengelolaan dan pengembangan obyek wisata masih mengandalkan insentif dan inisiatif dari pemerintah daerah, sedangkan pengelolaan oleh swasta dan masyarakat hanya bersifat sebagian, seperti misalnya sarana pendukung di waduk Sermo yang dilakukan secara swadaya oleh masyarakat sekitar. Beragamnya jenis obyek wisata di Kulon Progo dapat menjadi potensi dan investasi ekonomi yang besar di masa yang akan datang, baik itu bagi pemerintah, swasta maupun masyarakat sekitar. Namun, tentu saja dibutuhkan berbagai kebijakan proteksi yang tepat agar selalu tercipta kesinambungan di antara stakeholder terkait.

Terkait dengan usaha pemerintah daerah Kulon Progo mengembangkan pariwisata di daerahnya, ternyata fakta di lapangan terlihat berbeda. Pariwisata Kulon Progo yang memiliki potensi tinggi tersebut tidak mampu bersaing dengan daerah tetangganya, sebagaimana tergambar dalam Tabel 1.

Tabel 1 menggambarkan bahwa kemampuan obyek wisata daerah Kulon Progo pada tahun 2011 (545.743) masih jauh di bawah Kabupaten Sleman (2.509.251), Bantul (2.521.303) dan Kota Yogyakarta (3.456.343). Dilihat perkembangannya, wisata Kulon Progo mengalami penurunan dibandingkan Kabupaten Gunung Kidul (688.405) yang notabene memiliki akses dan akomodasi yang lebih sulit. Melihat data tersebut akan timbul banyak pertanyaan,

Tabel 1. Statistik Kepariwisataan Provinsi DIY Tahun 2011

\begin{tabular}{llccrr}
\hline & Kabupaten / Kota & \multicolumn{1}{c}{2008} & \multicolumn{1}{c}{2009} & \multicolumn{1}{c}{2010} & \multicolumn{1}{c}{2011} \\
\hline 1 & D.I Yogyakarta & 2.467 .383 & 3.428 .324 & 3.529 .525 & 3.456 .343 \\
2 & Sleman & 2.730 .273 & 3.593 .665 & 2.499 .877 & 2.509 .251 \\
3 & Bantul & 1.073 .941 & 1.447 .556 & 1.300 .042 & 2.521 .303 \\
4 & Kulon Progo & 543.821 & 421.951 & 436.958 & 545.743 \\
5 & Gunung Kidul & 427.021 & 538.990 & 488.085 & 688.405 \\
\hline \multicolumn{5}{l}{ Sumber: Statistik Kepariwisataan Provinsi Daerah Istimewa Yogyakarta (2011) }
\end{tabular}


mengapa daerah yang memiliki kapasitas pariwisata tinggi tidak mampu bersaing dengan daerah lainnya.

Banyaknya potensi wisata di Kulon Progo, sudah seharusnya membuat Kulon Progo unggul dalam hal pariwisata, atau setidaknya dapat bersaing dengan daerah tetangganya satu provinsi. Namun kenyataan di lapangan menunjukkan suatu kemunduran dalam hal pengembangan pariwisata lokal.

Selain ke-14 obyek wisata yang telah disebutkan dalam Perda Nomor 1 Tahun 2012, sebenarnya masih terdapat beberapa obyek wisata lain yang memiliki potensi ekonomi tinggi, seperti Waduk Sermo yang terletak di Kecamatan Kokap. Waduk Sermo ini adalah satu satu waduk yang terdapat di Daerah Istimewa Yogyakarta dengan luas kurang lebih 157 hektar. Waduk ini menjadi sarana vital bagi kegiatan pertanian di bawahnya. Sebagai satu satunya waduk yang terdapat di Daerah Istimewa Yogyakarta, waduk ini menjadi istimewa dan cocok digunakan untuk wisata yang menginginkan suasana yang tenang dan sejuk. Tempat ini juga memiliki spot memancing dan wahana perahu wisata. Kurangnya promosi dan keseriusan pengembangan dari pihak terkait membuat wisata ini seakan terpinggirkan dari sekian banyak wisata lain di Provinsi Daerah Istimewa Yogyakarta. Selain Waduk Sermo, masih terdapat obyek wisata lain yang pemasarannya belum maksimal seperti Puncak Suroloyo, Goa Kiskendo, Pantai Congot, dan beberapa lagi lainnya.

Kabupaten Kulon Progo sebagai daerah agraris, mayoritas penduduknya masih berusaha pada sektor pertanian. Dari hasil Pendataan Usaha Tani 2009 terdapat 51.877 Rumah Tangga Tani yang mengusahakan tanaman Padi, Jagung, Kedelai, dan Tebu (PJKT).

Potensi alam yang dimiliki Kabupaten Kulon Progo sudah seharusnya dilestarikan dengan baik. Pembangunan di bidang industri teknologi mungkin dilakukan, namun dalam rangka mendukung daerah swasembada panga. Hal ini tidak dapat dijadikan sebagai prioritas utama pembangunan. Salah satu industri yang dapat berjalan beriringan dengan konsep daerah agraris di Kabupaten Kulon Progo adalah pengembangan industri pariwisata. Sinergitas pariwisata, pertanian, dan peternakan sebagai industri yang ramah lingkungan. Salah satunya dapat diwujudkan melalui konsep desa wisata, seperti Desa Wisata Kalibawang, Desa Wisata Kalibiru, Desa Wisata Nglinggo, dan lain sebagainya.

Potensi pariwisata yang tinggi di wilayah Kulon Progo sudah seharusnya dapat dioptimalkan, bukan hanya dilihat sebagai potensi pendapatan daerah, namun sebagai salah satu upaya melestarikan kebudayaan daerah yang sudah mulai ditinggalkan. Sebagai salah satu motivator utama perkembangan industri, pariwisata Pemerintah daerah kabupaten Kulon Progo dibutuhkan peranannya baik itu untuk mengelola maupun memasarkan produk-produk pariwisata agar dapat menjadi sumber pendapatan potensial bagi daerah. Melalui berbagai terobosan kebijakannya, diharapkan pemerintah daerah mampu merangkul berbagai stakeholder demi keberlangsungan industri pariwisata yang berdaya saing dan berkelanjutan bertumpu pada pemberdayaan masyarakat. Berdasarkan uraian di atas, maka artikel ini akan membahas pengembangan pariwisata 
berbasis masyarakat (Community Based Tourism-CBT) sebagai strategi pemberdayaan ekonomi masyarakat di Kabupaten Kulon Progo Daerah Istimewa Yogyakarta.

\section{Pengembangan Pariwisata Berbasis Masyarakat sebagai Strategi Pember- dayaan Ekonomi Masyarakat}

Pemberdayaan masyarakat (komunitas setempat) yang berada di lokasi yang menjadi tujuan (destinasi) wisata melalui kegiatan usaha kepariwisataan merupakan salah satu model pembangunan yang sedang mendapatkan banyak perhatian dari berbagai kalangan dan akan menjadi agenda penting dalam pembangunan kepariwisataan di masa datang.

Adimihardja (1999) dalam Sunaryo (2013: 215) mendefinisikan pemberdayaan masyarakat sebagai suatu proses yang tidak saja hanya mengembangkan potensi ekonomi masyarakat yang sedang tidak berdaya. Akan tetapi, juga harus berupaya dapat meningkatkan harkat dan martabat, rasa percaya diri dan harga dirinya, dan terpeliharanya tatanan nilai budaya setempat. Pemberdayaan masyarakat dimaknai sebagai suatu upaya untuk menguatkan power (daya) atau empowering dari golongan masyarakat yang powerless (tidak berdaya), biasanya mereka yang tergolong ke dalam masyarakat yang marjinal.

Sinclair (1998) menyebutkan bahwa pariwisata mampu memberikan manfaat dalam bentuk penguatan ekonomi lokal, yang antara lain berupa devisa, pendapatan tambahan kepada masyarakat, serta peluang pekerjaan yang dapat ditangkap oleh masyarakat. Sektor usaha dalam pariwisata seperti usaha akomodasi, transportasi,dan lainnya dapat memberikan kontribusi dalam mendorong perekonomian lokal, regional, maupun nasional.

Dalam kegiatan kepariwisataan ada beberapa pihak yang memiliki peran dan terlibat langsung dalam kegiatan kepariwisataan. Gambar 1 menyajikan

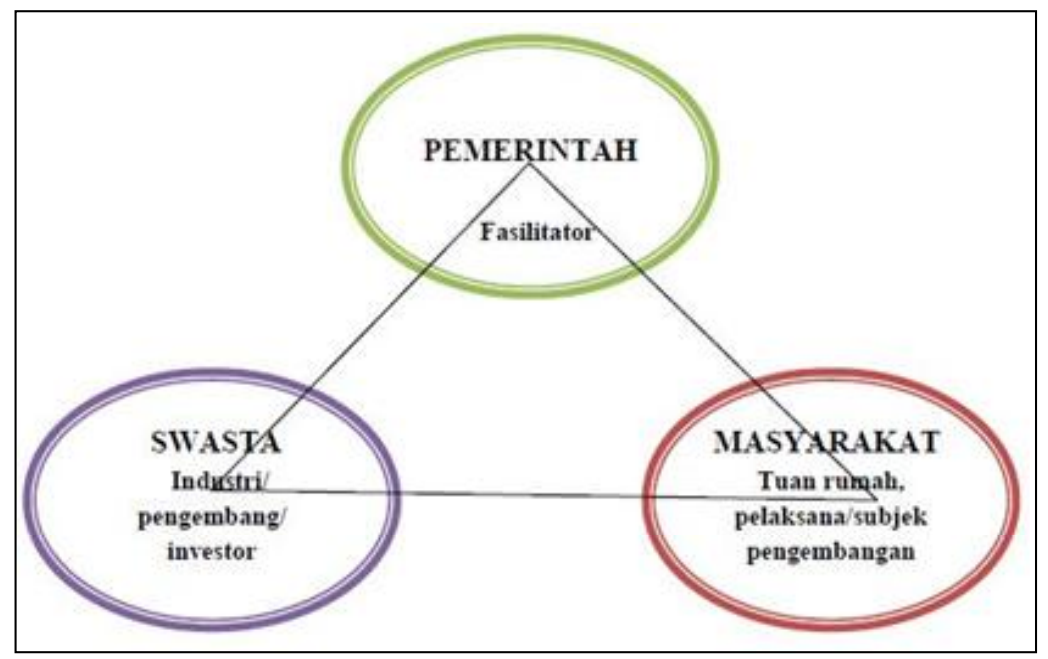

Gambar 1. Pemangku Kepentingan dalam Pariwisata (Sunaryo, 2013: 217) 
ilustrasi pemangku kepentingan dalam pariwisata.

Berdasarkan Gambar 1 dapat disimpulkan bahwa peran masyarakat dalam pelaksanaan kepariwisataan sangatlah besar dan perlu diseimbangkan dengan peran pemerintah maupun swasta. Tetapi dalam kenyataannya yang terjadi peran masyarakat masih sangat kecil bila dibandingkan dengan kedua stakeholder lainnya. Penyebabnya adalah tidak adanya atau lemahnya akses yang mereka miliki kepada sumberdaya (resource) pariwisata yang ada dan rendahnya pelibatan mereka dalam proses pengambilan keputusan.

Pentingnya pemberdayaan masyarakat dalam pengembangan kepariwisataan menjadi sorotan penting menurut pakar kepariwisataan dunia. Murphy (1988), Dawyer, Forsyth, dan Dwyer (2010) dalam Sunaryo (2013: 219) menyatakan bahwa pembangunan kepariwisataan harus merupakan suatu kegiatan yang berbasis pada komunitas. Dengan faktor utama sumber daya dan keunikan komunitas lokal, baik berupa elemen fisik maupun non fisik (tradisi dan budaya) yang melekat pada komunitas tersebut harus menjadi penggerak utama dalam pariwisata tersebut.

Sunaryo (2013: 218) menyatakan bahwa untuk mewujudkan pengembangan pariwisata berjalan dengan baik dan dikelola dengan baik maka hal yang paling mendasar dilakukan adalah bagaimana memfasilitasi keterlibatan yang luas dari komunitas lokal dalam proses pengembangan dan memaksimalkan nilai manfaat sosial dan ekonomi dari kegiatan pariwisata untuk masyarakat setempat. Masyarakat lokal memiliki kedudukan yang sama pentingnya sebagai salah satu pemangku kepentingan (stakeholder) dalam pembangunan kepariwisataan, selain pihak pemerintah dan industri swasta.

Berdasarkan konsep pemberdayaan masyarakat dalam pembangunan kepariwisataan maka upaya pemberdayaan masyarakat melalui kepariwisataan pada hakikatnya harus diarahkan pada beberapa hal sebagai berikut.

1. Meningkatnya kapasitas, peran dan inisiatif masyarakat pembangunan kepariwisataan.

2. Meningkatnya posisi dan kualitas keterlibatan/partisipasi masyarakat.

3. Meningkatnya nilai manfaat positif pembangunan kepariwisataan bagi kesejahteraan ekonomi masyarakat.

4. Meningkatnya kemampuan masyarakat dalam melakukan perjalanan wisata (Sunaryo, 2013: 219).

Lebih lanjut dikemukakan oleh Sunaryo (2013: 138) bahwa dalam pembangunan kepariwisataan yang berorientasi pada pemberdayaan masyarakat menjadi isu strategi pengembangan kepariwisataan saat ini. Dalam khasanah ilmu kepariwisataan, strategi tersebut dikenal dengan istilah community based tourism (CBT) atau pariwisata berbasis masyarakat. Konstruksi CBT ini pada prinsipnya merupakan salah satu gagasan yang penting dan kritis dalam perkembangan teori pembangunan kepariwisataan konvensional (growth oriented model) yang seringkali mendapatkan banyak kritik telah mengabaikan hak dan meminggirkan masyarakat lokal dari kegiatan kepariwisataan di suatu destinasi.

Murphy dalam Sunaryo (2013: 139) menyebutkan bahwa pada hakikatnya pembangunan kepariwisataan tidak bisa 
lepas dari sumber daya dan keunikan komunitas lokal, baik berupa elemen fisik maupun nonfisik (tradisi dan budaya), yang merupakan unsur penggerak utama kegiatan wisata itu sendiri. Kepariwisataan harus dipandang sebagai kegiatan yang berbasis pada komunitas. Batasan pengertian pariwisata berbasis masyarakat sebagai berikut.

1. Wujud tata kelola kepariwisataan yang memberikan kesempatan kepada masyarakat lokal untuk mengontrol dan terlibat aktif dalam manajemen dan pembangunan kepariwisataan yang ada.

2. Wujud tata kelola kepariwisataan yang dapat memberikan kesempatan pada masyarakat yang terlibat langsung dalam usaha-usaha kepariwisataan juga bisa mendapatkan keuntungan dari kepariwisataan yang ada.

3. Bentuk kepariwisataan yang menuntut pemberdayaan secara sistematik dan demokratis serta distribusi keuntungan yang adil kepada masyarakat yang kurang beruntung yang ada di destinasi.

Pariwisata berbasis masyarakat berkaitan erat dengan adanya kepastian partisipasi aktif dari masyarakat setempat dalam pembangunan kepariwisataan yang ada. Partisipasi masyarakat dalam pariwisata terdiri dari atas dua perspektif, yaitu partisipasi masyarakat dalam proses pengambilan keputusan dan partisipasi yang berkaitan dengan distribusi keuntungan yang diterima oleh masyarakat dari pembangunan pariwisata. Oleh karena itu, pada dasarnya terdapat tiga prinsip pokok dalam strategi perencanaan pembangunan kepariwisatan yang berbasis pada masyarakat atau community based tourism, yaitu:
1. Mengikutsertakan anggota masyarakat dalam pengambilan keputusan.

2. Adanya kepastian masyarakat lokal menerima manfaat dari kegiatan kepariwisataan.

3. Pendidikan Kepariwisataan bagi masyarakat lokal (Sunaryo, 2013: 140).

Suansri (2003) menyebutkan beberapa prinsip dari $C B T$ yang harus dilakukan, yaitu: (1) mengenali, mendukung, dan mempromosikan kepemilikan masyarakat dalam pariwisata, (2) melibatkan anggota masyarakat dari setiap tahap pengembangan pariwisata dalam berbagai aspeknya, (3) mempromosikan kebanggaan terhadap komunitas bersangkutan, (4) meningkatkan kualitas kehidupan, (5) menjamin keberlanjutan lingkungan, (6) melindungi ciri khas (keunikan) dan budaya masyarakat lokal, (7) mengembangkan pembelajaran lintas budaya, (8) menghormati perbedaan budaya dan martabat manusia, (9) mendistribusikan keuntungan dan manfaat yang diperoleh secara proporsional kepada anggota masyarakat, (10) memberikan kontribusi dengan persentase tertentu dari pendapatan yang diperoleh untuk pengembangan masyarakat, dan (11) menonjolkan keaslian hubungan masyarakat dengan lingkungannya.

Berdasarkan pendapat tersebut terlihat bahwa CBT sangat berbeda dengan pengembangan pariwisata pada umumnya (mass tourism). Dalam CBT, komunitas merupakan aktor utama dalam proses pembangunan pariwisata, dengan tujuan utama untuk peningkatan standar kehidupan masyarakat. 


\section{METODE}

Artikel ini merupakan hasil penelitian deskriptif kualitatif. Penelitian bertujuan untuk mendeskripsikan dan menganalisis upaya pemerintah Kabupaten Kulon Progo dalam mengembangkan pariwisata berbasis masyarakat, mengidentifikasi jenis pariwisata yang potensial untuk dikembangkan menjadi pariwisata berbasis masyarakat, mendapatkan informasi hambatan yang menyebabkan pariwisata berbasis masyarakat di Kabupaten Kulon Progo tidak dapat berkembang optimal, dan merumuskan model pengembangan pariwisata berbasis masyarakat di Kabupaten Kulon Progo.

Melalui penelitian deskriptif kualitatif peneliti leluasa untuk memperoleh data dan fakta hingga mencapai titik jenuh, sehingga data yang diperoleh mampu menjawab pertanyaan permasalahan penelitian ini.

Dalam menyelesaikan penelitian ini, peneliti menggunakan prosedur penelitian dan pengembangan (Research and Development) yang dikembangkan oleh Borg and Gall. Penelitian direncanakan dilaksanakan dalam dua (2) tahun, dengan tahapan kegiatan penelitian tahun pertama adalah melakukan eksplorasi dan pada tahun kedua adalah implementasi dan diseminasi.

Tanpa mengurangi validitas proses dan temuan hasil penelitian ini, Research and Development yang dikembangkan oleh Borg and Gall dalam penelitian ini dilakukan adaptasi dan modifikasi dalam tahapannya menjadi sebagai berikut: (1) meneliti dan mengumpulkan informasi tentang kebutuhan pengembangan CBT, (2) merencanakan prototipe komponen yang akan dikembangkan, (3) mengembangkan prototipe awal untuk dijadikan model, (4) melakukan validasi model konseptual kepada para ahli dan praktisi di bidang kepariwisataan, (5) melakukan uji coba terbatas (uji coba 1) terhadap model awal, (6) merevisi model awal, berdasarkan hasil uji coba dan analisis data, (7) melakukan uji coba 2 terhadap model yang sudah direvisi, (8) melakukan revisi akhir atau penghalusan model, apabila peneliti dan pihak terkait menilai proses dan produk yang dihasilkan belum memuaskan, dan (9) melakukan implementasi dan diseminasi kepada berbagai pihak.

\section{HASIL DAN PEMBAHASAN}

Potensi pariwisata Kabupaten Kulon Progo sebagaimana dideskripsikan di atas lebih menitikberatkan kepada obyek pariwisata konvensional (mass tourism) yang pada suatu ketika dapat mengalami kejenuhan, sehingga pemerintah Kabupaten Kulon Progo mencari alternatif pengembangan pariwisata yang melibatkan masyarakat.

Upaya pengembangan destinasi pariwisata di Kabupaten Kulon Progo dilakukan melalui: (1) program pengembangan pariwisata, (2) pengembangan pemasaran pariwisata, dan (3) pengembangan kemitraan pariwisata. Pengembangan destinasi pariwisata merupakan upaya untuk menata kawasan, dan kondisi obyek wisata, serta menyediakan dan melengkapi sarana dan prasarana pariwisata. Pelaksanaan program ini dicapai melalui kegiatan pengembangan obyek pariwisata unggulan, pengembangan jenis dan paket wisata unggulan melalui penyedian fasilitas layanan, pengembangan daerah tujuan wisata, peningkatan pembangunan sarana prasarana pariwisata, pengelolaan retribusi obyek wisata berupa pembayaran upah pungut kepada kelompok pemungut retribusi di 
obyek wisata, serta pembayaran premi asuransi pengunjung obyek wisata dan penyusunan perangkat hukum dan perencanaan pariwisata.

Program pengembangan pemasaran pariwisata dimaksudkan guna mengenalkan, menginformasikan dan mempromosikan pariwisata yang ada di Kulon Progo pada pasar wisata potensial baik regional, nasional bahkan internasional. Program ini dilaksanakan melalui kegiatan peningkatan pemanfaatan teknologi informasi dalam pemasaran pariwisata, kegiatan pengembangan jaringan kerjasama promosi pariwisata bersama Java Promo dan Travel Dialog bersama kabupaten/kota di DIY ke luar daerah, diikuti pula kegiatan pelaksanaan promosi pariwisata nusantara di dalam dan di luar negeri melalui Gebyar Wisata Nusantara di Jakarta. Dalam rangka mempromosikan serta menambah daya tarik kunjungan di obyek wisata, dilaksanakan kegiatan penyelenggaraan atraksi di obyek wisata.

Program pengembangan kemitraan dilaksanakan guna meningkatkan kapasitas dan peran serta pelaku pariwisata dan masyarakat dalam pengembangan pariwisata. Program ini dilaksanakan melalui kegiatan Komunikasi Informasi dan Edukasi (KIE) bagi pengelola hotel dan pengelola desa wisata, monitoring, evaluasi, dan pelaporan pengembangan kemitraan dengan sasaran desa wisata dan pelaku usaha pariwisata yang ada di Kabupaten Kulon Progo.

Jenis pariwisata yang potensial untuk dikembangkan menjadi CBT di Kulon Progo disajikan pada Tabel 2.

Potensi pariwisata yang dikembangkan sebagai model pengembangan CBT di Kabupaten Kulonprogo dapat dikelompokkan dalam: (1) wisata sosialbudaya untuk pengembangan wilayah
Kulonprogo Tengah dan Selatan; (2) wisata pertanian untuk pengembangan wilayah Kulonprogo Utara dan Tengah; dan (3) wisata alam dan lingkungan untuk pengembangan wilayah Kulonprogo Utara khususnya di perbukitan Menoreh dan pantai selatan. Jenis pariwisata tersebut akan melibatkan partisipasi masyarakat baik sebagai pelaku langsung maupun sebagai pendukung pariwisata. Kegiatan pariwisata di atas juga dapat membangun jiwa kewirausahaan dan kreativitas masyarakat sehingga akan terjadi multiplier effects yang dapat menyejahterakan apabila dikelola dengan baik.

Pemerintah Kabupaten Kulon Progo menghadapi berbagai hambatan dalam mengembangkan CBT. Hambatan tersebut antara lain: (1) sumber dana yang tidak mencukupi, (2) kurangnya jumlah sumber daya manusia di bidang pengembangan pariwisata, (3) kesiapan masyarakat dalam menyikapi pentingnya pengembangan pariwisata, mayoritas masyarakat yang hidup sebagai petani cenderung apatis dan kurang sadar akan hal tersebut, akibatnya inovasi dan kreasi dari pihak masyarakat terkait dengan pengembangan pariwisata tidak dapat optimal, dan (4) dukungan dari pihak swasta atau pengusaha wisata juga masih minim, kurangnya investor yang mau untuk turut mengembangkan potensi CBT.

Model pengembangan CBT sebagai strategi pemberdayaan ekonomi masyarakat lokal di Kabupaten Kulonprogo dirumuskan dengan berdasarkan pertimbangan potensi dan permasalahan yang ada. Model ini dirumuskan melalui forum focus group discussion (FGD) yang melibatkan pihak Pemerintah Kabupaten Kulonprogo, NGO's, pusat studi pariwisata, ahli kepariwisataan dari 
Tabel 2. Desa Wisata di Kabupaten Kulon Progo

\begin{tabular}{|c|c|c|}
\hline No & Nama Desa Wisata & Aktivitas/Paket Kegiatan \\
\hline 1. & $\begin{array}{l}\text { Desa Wisata Nglinggo } \\
\text { (Pagerharjo, Samigaluh) }\end{array}$ & $\begin{array}{l}\text { Tracking ke air terjun Watu Jonggol dan menikmati pesona } \\
\text { alam bukit Menoreh; budaya (Lengger Tapeng, Jathilan); agro } \\
\text { (perkebunan kopi, teh); kuliner (nasi jagung, gula aren, kopi, } \\
\text { dengan membuat dan menikmati dan menyeduh sendiri); } \\
\text { tracking di Bukit Menoreh di antara perkebunan kopi dan teh }\end{array}$ \\
\hline 2. & $\begin{array}{l}\text { Desa Wisata Pendowo- } \\
\text { rejo (Pendoworejo, } \\
\text { Girimulyo) }\end{array}$ & $\begin{array}{l}\text { Alam (Bendung Kayangan, pesona alam pegunungan); } \\
\text { budaya (belajar menari, karawitan, jathilan, kethoprak, } \\
\text { membuat batik); tracking keliling desa }\end{array}$ \\
\hline 3. & $\begin{array}{l}\text { Dewi Asri } \\
\text { Desa Wisata Banjarasri } \\
\text { (Banjarasri, } \\
\text { Kalibawang) }\end{array}$ & $\begin{array}{l}\text { Aneka permainan air (river tubing, river boat, gethek } \\
\text { air); penerapan Teknologi Tepat Guna (teknologi biogas); } \\
\text { tracking, bird watching, mountain bike; belajar menjadi } \\
\text { petani; permainan desa (egrang, bakiak, tangkap belut); } \\
\text { belajar sejarah (napak tilas P. Diponegoro, jejak misionaris, } \\
\text { jejak sejarah perjuangan AH. Nasution) }\end{array}$ \\
\hline 4. & $\begin{array}{l}\text { "Dewa Bara" } \\
\text { Desa Wisata Banjaroya } \\
\text { (Banjaroya, } \\
\text { Kalibawang) }\end{array}$ & $\begin{array}{l}\text { Belajar pembibitan dan pengolahan kakao dan durian, gamelan } \\
\text { dan tari, proses pembuatan gula jawa; kuliner wedang badeg; } \\
\text { tracking, bersepeda, dan outbound; susur Sungai Progo pasca } \\
\text { erupsi merapi; paket live in "andai aku menjadi" }\end{array}$ \\
\hline 5. & $\begin{array}{l}\text { "Dewi Glagah" } \\
\text { Desa Wisata Glagah } \\
\text { (Glagah, Temon) }\end{array}$ & $\begin{array}{l}\text { Tracking bersepeda susur desa dan susur pantai; berperahu di } \\
\text { laguna, menikmati kuliner laut; budaya (Labuhan Pakualaman); } \\
\text { agro (petik buah naga); wisata tirta ( dayung di laguna, perahu } \\
\text { naga) }\end{array}$ \\
\hline 6. & $\begin{array}{l}\text { Desa Wisata Sermo } \\
\text { (Sermo, Hargowilis, } \\
\text { Kokap) }\end{array}$ & $\begin{array}{l}\text { Tracking dan bersepeda menikmati pesona alam bukit Menoreh } \\
\text { dan berkeliling Waduk Sermo; budaya; agro (suaka alam } \\
\text { margasatwa, dan tanaman); olahraga tirta (dayung, kayak/ } \\
\text { kano, perahu naga) }\end{array}$ \\
\hline 7. & $\begin{array}{l}\text { Desa Wisata Jatimulyo } \\
\text { (Jatimulyo, Girimulyo) }\end{array}$ & $\begin{array}{l}\text { Alam (Goa Kiskendo, Watu Blencong, Grojogan Sewu, Gunung } \\
\text { Ndangsri-burung, Gunung Asinan-anggrek); budaya (jathilan, } \\
\text { angguk, karawitan, wayang kulit); kuliner (sego urap, sambel } \\
\text { korek, aneka wedang jahe); agro (salak, kopi, coklat,anggrek); } \\
\text { peternakan (kambing PE); petualangan (camping ground) }\end{array}$ \\
\hline 8. & $\begin{array}{l}\text { Desa Wisata Kalibiru } \\
\text { (Kalibiru, Hargowilis, } \\
\text { Kokap) }\end{array}$ & $\begin{array}{l}\text { Alam (pesona pegunungan); petualangan ( outbond, camping } \\
\text { ground, cottage) }\end{array}$ \\
\hline 9. & $\begin{array}{l}\text { Desa Wisata Sidoharjo } \\
\text { (Samigaluh) }\end{array}$ & $\begin{array}{l}\text { Tracking pesona alam perbukitan; menikmati air terjun Curug } \\
\text { dan mata air Tukmudal; adventure; Coffee Tour; menikmati dan } \\
\text { belajar seni budaya }\end{array}$ \\
\hline 10. & $\begin{array}{l}\text { Desa Wisata Sidorejo } \\
\text { (Lendah) }\end{array}$ & Menikmati alam (Bendung Sapon); Tracking; belajar membatik \\
\hline 11. & $\begin{array}{l}\text { Desa Wisata } \\
\text { Purwoharjo } \\
\text { (Samigaluh) }\end{array}$ & $\begin{array}{l}\text { Menikmati alam Goa Sriti; Tracking susur sungai Tinalah; } \\
\text { Tracking Sepeda Gunung; Hiking; Camping; Panjat Tebing; } \\
\text { Wisata sejarah (Pengikut P. Diponegoro) dan Sejarah } \\
\text { Perjuangan (Sandi Negara utusan TB Simatupang) }\end{array}$ \\
\hline
\end{tabular}

Sumber: Dinbudparpora Kab. Kulon Progo, 2012 
perguruan tinggi, swasta, dan kelompok sadar wisata. Adapun model yang disusun disajikan pada Gambar 2 .
Kabupaten Kulon Progo memiliki banyak potensi pariwisata yang dapat dikembangkan menjadi CBT. Potensi

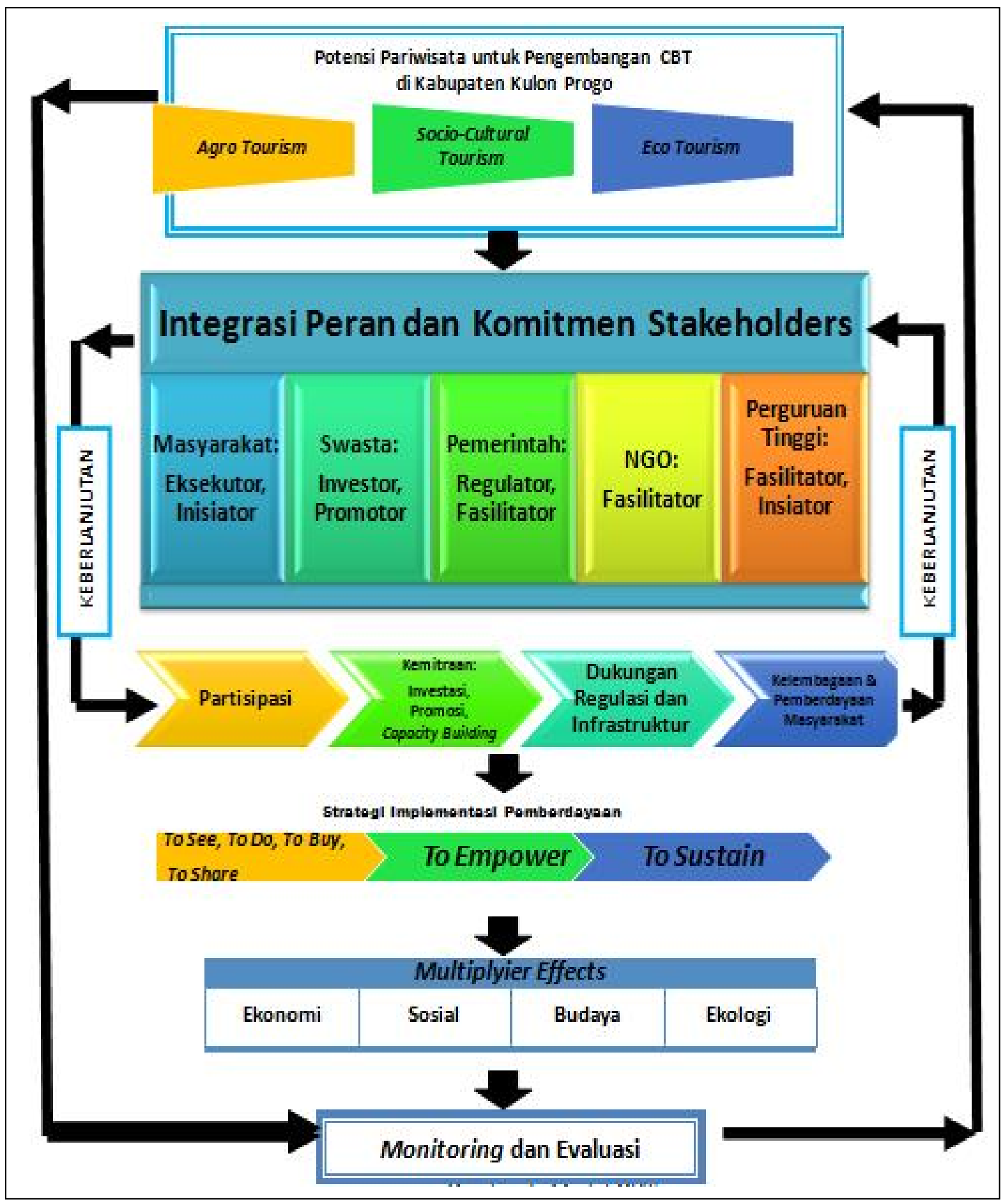

Gambar 1. Model CBT 
tersebut berupa wisata alam (back to nature), kesenian tradisional, kerajinan, wisata religi, wisata pendidikan dan wisata minat khusus (special interest). Dalam Upaya pengembangan destinasi pariwisata di Kabupaten Kulon Progo dilakukan melalui: (1) program pengembangan pariwisata, (2) pengembangan pemasaran pariwisata, dan (3) pengembangan kemitraan pariwisata.

Potensi pariwisata yang dikembangkan sebagai model pengembangan CBT di Kabupaten Kulonprogo dapat dikelompokkan dalam: (1) Wisata sosial-budaya; untuk pengembangan wilayah Kulonprogo Tengah dan Selatan; (2) Wisata pertanian; untuk pengembangan wilayah Kulonprogo Utara dan Tengah; dan (3) Wisata alam dan lingkungan; untuk pengembangan wilayah Kulonprogo Utara khususnya di perbukitan Menoreh dan pantai selatan. Jenis pariwisata tersebut akan melibatkan partisipasi masyarakat baik sebagai pelaku langsung maupun sebagai pendukung pariwisata. Kegiatan pariwisata di atas juga dapat membangun jiwa kewirausahaan dan kreativitas masyarakat sehingga akan terjadi multiplier effects yang dapat menyejahterakan masyarakat apabila dikelola dengan baik.

Namun demikian, dalam pengembangan pariwisata dan khususnya CBT, terdapat beberapa kendala yang dihadapi yaitu: (1) sumber dana yang tidak mencukupi, (2) kurangnya jumlah sumber daya manusia di bidang pengembangan pariwisata, (3) kekurangsiapan masyarakat dalam menyikapi pentingnya pengembangan pariwisata disebabkan mayoritas masyarakat yang hidup sebagai petani cenderung apatis dan kurang sadar akan hal tersebut. Akibatnya, inovasi dan kreasi dari pihak masyarakat terkait dengan pengembangan pariwisata tidak dapat optimal, (4) dukungan dari pihak swasta atau pengusaha wisata juga masih minim, khususnya investor yang mau untuk turut mengembangkan potensi CBT.

Pengembangan CBT di Kabupaten Kulon Progo akan bermanfaat dalam menciptakan kesempatan kerja, mengurangi tingkat kemiskinan, pelestarian lingkungan dan budaya setempat sehingga akan dapat memberdayakan ekonomi masyarakat. Model pengembangan CBT sebagai strategi pemberdayaan ekonomi masyarakat lokal di Kabupaten Kulonprogo dirumuskan dengan berdasarkan pertimbangan potensi dan permasalahan yang ada. Model pengembangan CBT tersebut akan berhasil apabila semua komponen tersedia dan mendapat dukungan dari stakeholders. Dukungan tersebut berupa keberpihakan dalam bentuk program dan regulasi, modal usaha, kemitraan, maupun keterlibatan masyarakat dan infrastruktur.

Dalam pengembangan CBT terdapat beberapa saran yang dapat dilaksanakan oleh Pemerintah Kabupaten Kulon Progo, yaitu: (1) Peningkatan partisipasi seluruh stakeholders termasuk masyarakat dalam mengembangkan potensi wisata di Kulon Progo. (2) Peningkatan anggaran guna pengembangan pariwisata melalui kegiatan-kegiatan kreatif dan inovatif dengan tetap memperhatikan karakteristik wilayah. (3) Peningkatan kuantitas dan kualitas sumber daya manusia pendukung sektor pariwisata. (4) Peningkatan upaya membangun kesadaran masyarakat akan pentingnya pengembangan pariwisata melalui pelatihan dan workshop. (5) Model pengembangan CBT yang telah dirumuskan perlu segera diimplementasikan dan didesiminasikan, mengingat saat ini 
Kabupaten Kulon Progo sudah memetakan pengembangan wilayah pariwisata mulai dari perbukitan Menoreh sampai dengan pantai selatan. Jenis pariwisata tersebut akan melibatkan partisipasi masyarakat baik sebagai pelaku langsung maupun sebagai pendukung pariwisata.

\section{DAFTAR PUSTAKA}

Sinclair, T. 1998. Tourism and Economic Development: A survey. Journal of Development Studies, 5, 1-51.

Spillane, J. J. 1987. Ekonomi Pariwisata

Sejarah dan Prospeknya. Yogyakarta: Kanisius.

Suansri, P. 2003. Comunity Based TourismHandbook. Bangkok, Thailand:
Responsible Ecological Social Tours (REST) Project.

Sunaryo, B. 2013. Kebijakan Pembangunan Destinasi Pariwisata Konsep dan Aplikasinya di Indonesia. Yogyakarta: Gava Media.

Statistik Kepariwisataan Provinsi Daerah Istimewa Yogyakarta Tahun 2011.

Peraturan Daerah Kabupaten Kulon Progo Nomor 1 Tahun 2012 tentang Rencana Tata Ruang Kabupaten Kulon Progo.

Undang-Undang Nomor 32 tahun 2004 tentang Pemerintahan Daerah.

Undang-Undang Nomor 33 tahun 2004 tentang Perimbangan Keuangan Antara Pemerintah Pusat dan Pemerintah Daerah 